\title{
ABOUT CREATION OF BOGIE OF THE FREIGHT CAR
}

\begin{abstract}
Analyses of the operating problems of freight car bogies are carried out, as well as the reasons resulting in deterioration of the dynamic characteristics of modern bogies are specified. The main directions of modernization of existing bogie structures and the creation of fundamentally new designs of the bogies are planned.

It is reasonable to design a bogie based on hire and using the multifunctional modules and pre-stressed structures. It would allow to reduce the weight of bogies, improve their strength and dynamic properties, and increase the speed of movement. Design solutions for improving the strength and dynamic properties of bogies implementing these principles, are proposed.

Keywords: Freight car, bogie, pre-stressed structures, creation of a specialized profile, elastic-damping multifunctional elements.
\end{abstract}

\section{Introduction}

Over a decade, the world's leading research centers have been engaged in improving the running gear of freight cars. For Europe, these studies are carried out within the framework of the EU Road Map, according to which, in order to reduce the energy dependence of the transport sector and to reduce emissions of harmful substances into the atmosphere, it is planned that by $203030 \%$ of goods transported by road will be redirected to river and railway transport, and by $205050 \%$ of freight will be transported by river and railway transport [1]. This background requires the introduction of significant innovations and modernization of the fleet of cars, for example, the working program Shift 2 Rail [2] aims to achieve:

- reducing the weight of the body up to $30 \%$ and the weight of the bogie (reducing unsprung weight, which allows to reduce wear, noise and vibration and will reduce by $20 \%$ the life cycle cost of the bogie);

- reducing the dynamic impact on the track through the use of active suspension;

- reducing maintenance costs by $20 \%$ through the introduction of monitoring systems, mechatronic systems, etc.;

- reducing wheel and rails wear by $25 \%$, including when passing the curved track sections;

- increasing the speed of movement, especially for freight rail transport (Fig. 1) demonstrates the dynamic development of passenger rail transport and the "stagnation" of freight rail transport in terms of speed on the example of Sweden [3]).
Abundantly used in the EU and CIS countries bogie designs, such as Y-25, G-type, UIC Link suspension, Barber, have a rich history and have undergone only minor transformations during their existence, their evolution is shown in Fig. 2. The innovation matrix created as a part of SUSTRAIL project [4] has shown that the leading research centers in Europe consider Y-25 bogie as the basis of the freight bogie of the future. Within the framework of the conventional approach, it should be modified in the primary spring suspension, use two Lenoir dampers, material with good damping properties, new wheel contour and new wheel steel type. Within the futuristic concept, in addition to the outlined, the use of wedges, hydraulic dampers, and changes in the stiffness of the supports are supposed. Yet it should be noted that the Y-25 bogie is very sensitive to the track irregularities, and also requires the improvement of the dynamic qualities for the passage of curved track sections (Fig. 3) [5].

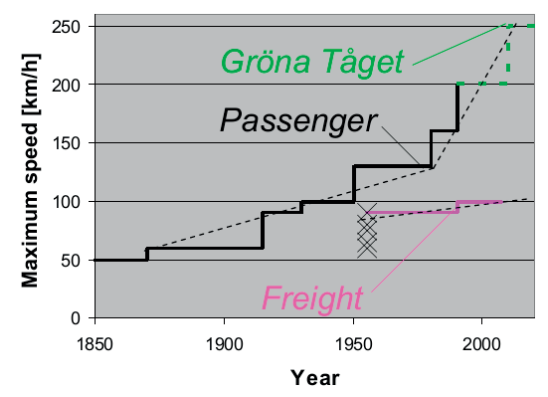

Fig. 1 Evolution of the maximum speeds of passenger and freight rail transport in Sweden [3]

\footnotetext{
* ${ }^{1}$ Juraj Gerlici, ${ }^{2}$ Mykola Gorbunov, ${ }^{1}$ Olena Nozhenko, ${ }^{3}$ Vaclav Pistek, ${ }^{2}$ Sergiy Kara, ${ }^{1}$ Tomas Lack, ${ }^{2}$ Kostiantyn Kravchenko ${ }^{1}$ Department of Transport and Handling Machines, Faculty of Mechanical Engineering, University of Zilina, Slovakia ${ }^{2}$ Department of Rail Transport, Institute of Transport and Logistics, Volodymyr Dahl East Ukrainian National University, Ukraine ${ }^{3}$ Faculty of Mechanical Engineering, Institute of Automotive Engineering, Brno University of Technology, Czech Republic E-mail: juraj.gerlici@fstroj.uniza.sk
} 

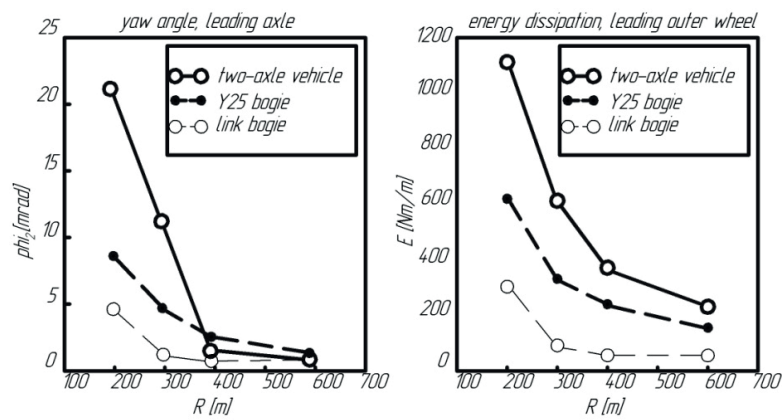

Fig. 3 The angle of attack and the dissipation energy of the first wheel pair

of different types of bogies when passing curves of different radii [5]
Unlike the authors [4], Sticheland S. and Jonsson consider it promising to use Link suspension bogie with hydraulic dampers [6], which allows to achieve speeds of up to $160 \mathrm{~km} / \mathrm{h}$.

In the countries of Central and Eastern Europe, a three-piece bogie is widely used (18 - 100 type or Barber) which is no better: maximum operating speed does not exceed $90-100 \mathrm{~km} / \mathrm{h}$, the high dynamic impact on the railway track is one of the main causes of its wear and damage, high dynamic loading of the supporting members, absence of the pedestal bogie primary suspension, cast bogie frame [7 - 8]. In different years, attempts have been made to optimize the characteristics of bogie suspension [9-10], the use of elastic elements in the pedestal [11 - 13], transition from cast to welded elements [14], but no significant breakthrough and tangible results have been achieved.

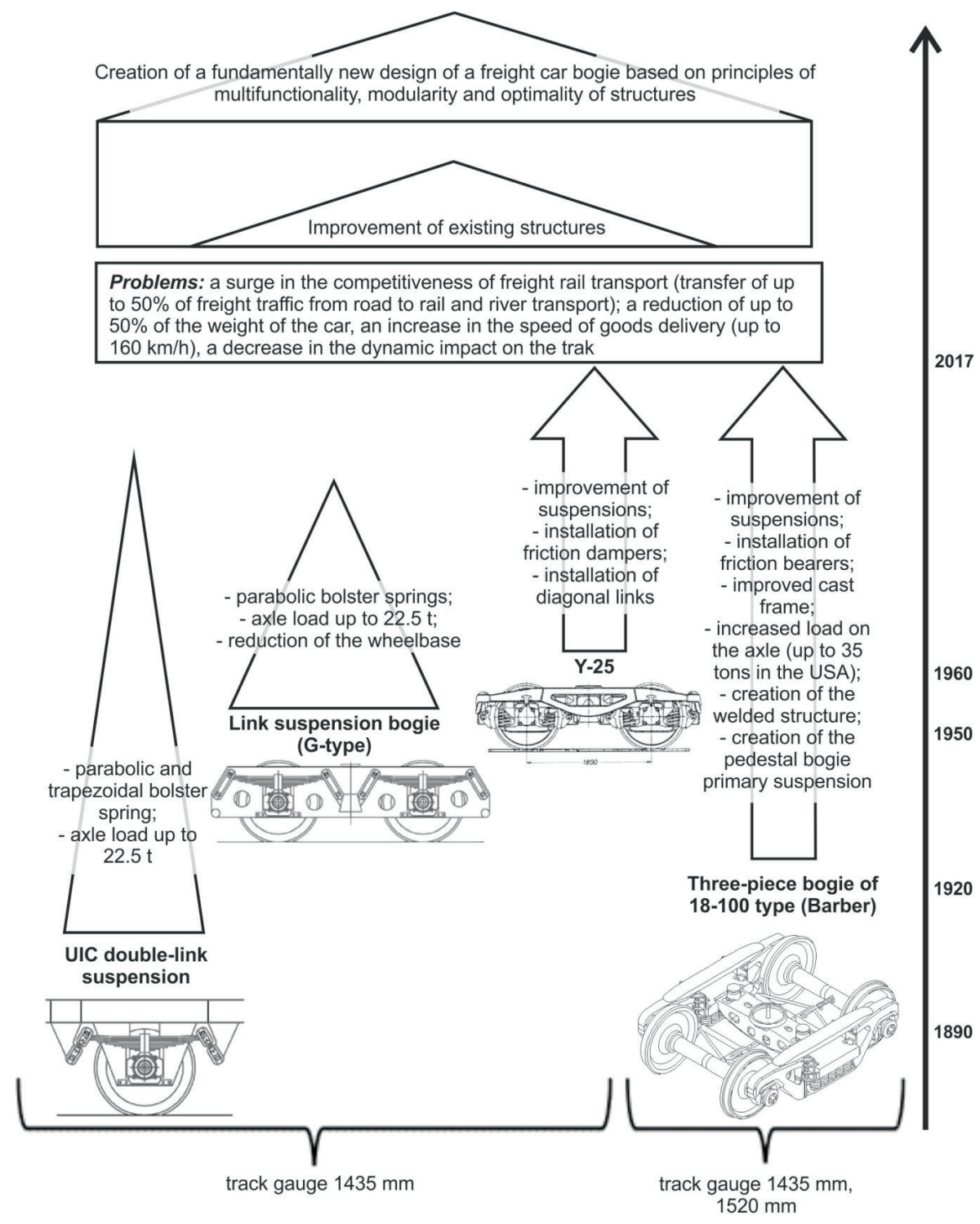

Fig. 2 Types of bogies used in the EU and CIS countries and their evolution 


\section{Methods for creating a fundamentally new design for a freight car bogie}

Thus, it is necessary to introduce breakthrough ideas, to develop a fundamentally new bogie design, with the implementation of advanced construction techniques, such as multi-functional components, design modularity, the use of new materials, the creation of the bogie with limiting parameters, the use of pre-stressed structures. In the immediate future, it is hardly possible to introduce drastic changes in the design of widely used bogies due to the repair base, but at the same time work on the creation of a fundamentally new design should be carried out now.

The authors of the article suggest a number of ways to improve freight car bogies of different types on the basis of the approach outlined above:

- $\quad$ using of pre-stressed structures;

- using of rolling materials, the creation of a specialized profile; - using of elastic-damping multifunctional elements with modularity units.

\subsection{Using of pre-stressed structures}

The authors propose the use of pre-stressed elements of the bogie design: truck bolster (Fig. 4) [15], side frame (Fig. 5) [16]; side frame pedestal jaw opening (Fig. 6) [17].

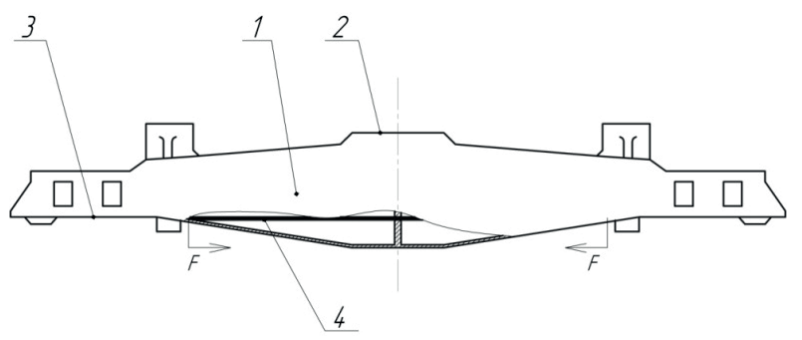

Fig. 4 Pre-stressed bolster of a three-piece bogie concept 1 truck bolster; 2 bolster bowl; 3 support bearing; 4 rod

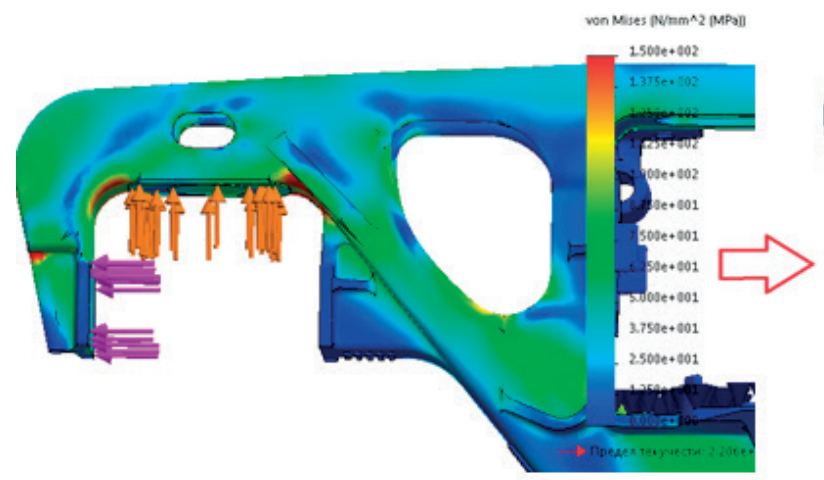

a)

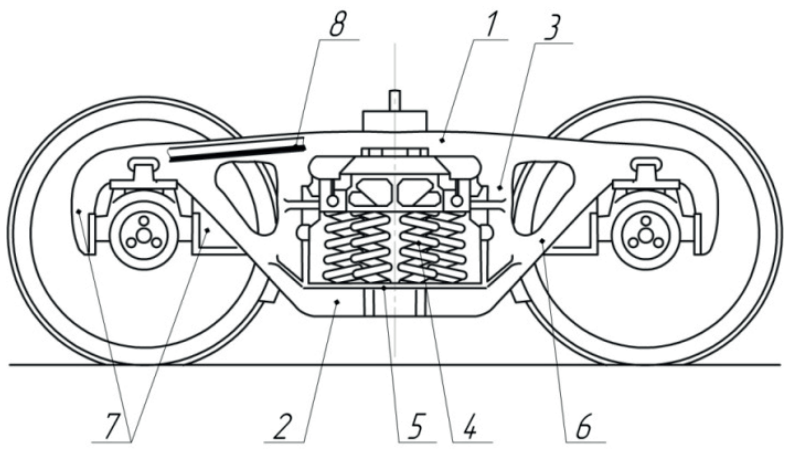

Fig. 5 Pre-stressed side frame of a three-piece bogie concept 1 top sole bar member; 2 lower sole bar member; 3 vertical columns; 4 spring opening; 5 bearing surface; 6 diagonal sole bar member; 7 jaw pedestal; 8 rod

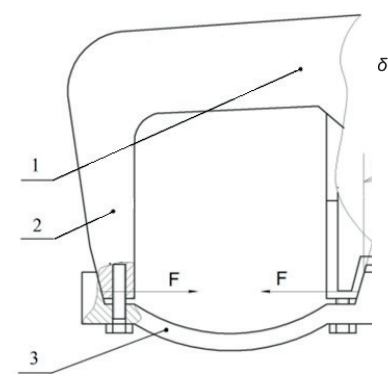

a)

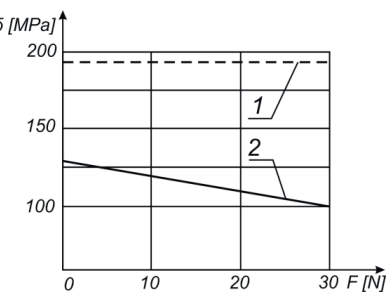

b)
Fig. 6 Pre-stressed pedestal jaw opening of a three-piece bogie concept: a) pre-stressing circuit in pedestal jaw opening,

b) dependence of the level of maximum stresses in the zone R55

(at maximum vertical and axial loads) on the force of preliminary

tightening of the jaws with pedestal brace (metal string)

1 - top sole bar member, 2 - pedestal jaw, 3 - pedestal brace, $\alpha$-angle of inclination, providing the preliminary tension of the structure, $F$-force providing pre-stressed state of a structure

As a result of strength calculations, by the finite element method, it was found out that by changing the force creating a

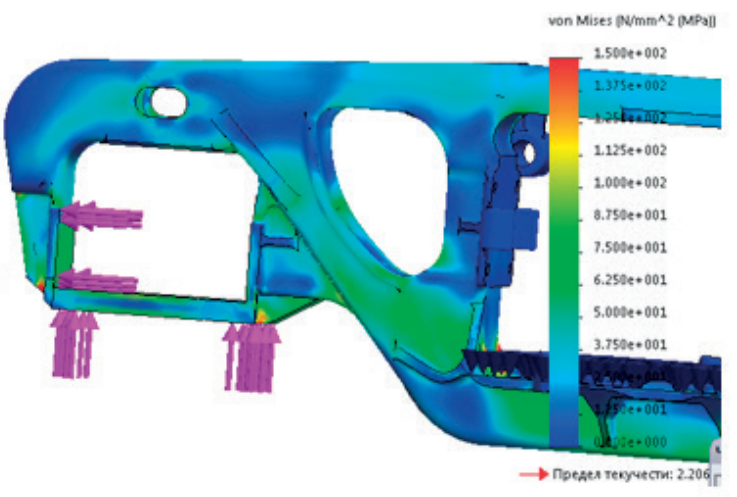

b)

Fig. 7 Distribution of equivalent stresses in the side frame: a) in existing bogie, b) in a bogie with a pre-stressed pedestal jaw opening 
preliminary stress in the pedestal jaw opening; it is possible to reduce the level of maximum stresses in the most stressed zone by 1.5 to 1.9 times - Fig. 7.

As the development of the idea of using a load-bearing element that closes the pedestal jaw opening, the authors developed technical solutions for the creation of primary bogie suspension in a three-piece bogie. An example of a design with coil springs is shown in Fig. 8 [9 - 10]. A preliminary calculation of the distribution of equivalent stresses in the side frame of the created structure is shown in Fig. 9: the change in the scheme of application of forces did not lead to an increase in the level of stresses.

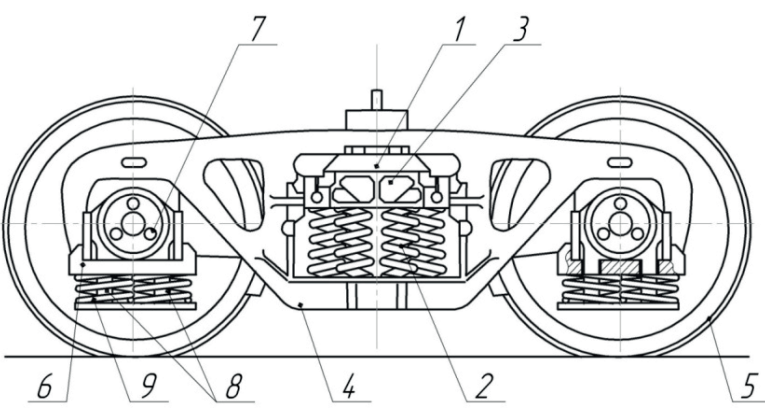

Fig. 8 Three-piece bogie with the pedestal braceand primary bogie suspension:

1- bolster, 2 - bolster suspension, 3 - friction shock absorbers, 4 - side frame, 5 - wheelsets, 6 - pedestal brace, 7 - axle-box, 8 - rods connecting the bearing with a stiffener, 9 - primary spring suspension

According to the preliminary calculation [12], deflection in the primary bogie suspension allows to reduce resistance to movement of the freight car by $11 \%$, and also to increase the speed of movement by $30 \%$ with an equivalent level of impact on the track.

\subsection{Using of rolling materials}

The next direction of modernization of the freight car bogies is the upcoming use of rolled stock which is close to equallystressed. Strength characteristics of such profiles are significantly higher than those of cast parts, and also have advantages over welded structures. Having higher indices of permissible stresses in the rolled product and its optimum profile, it is possible to reduce the weight of the bogie, increasing the energy efficiency of the rolling stock.

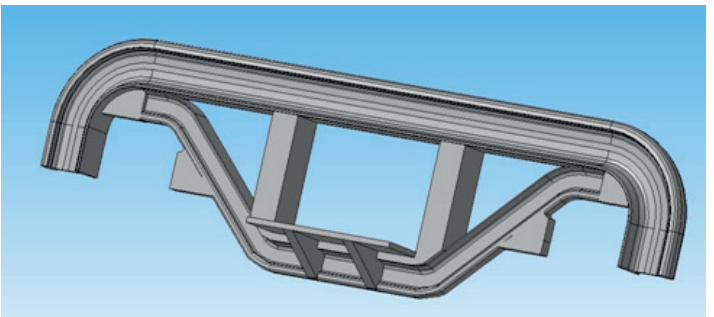

a)

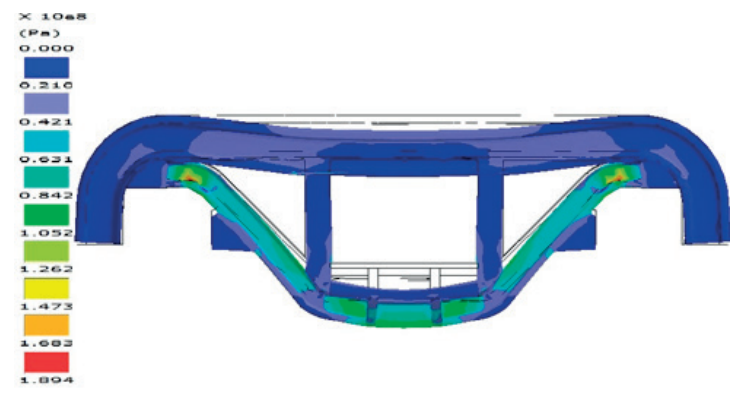

b)

Fig. 10 The conceptual scheme (a) and the distribution of equivalent stresses $(b)$ in the side frame of the bogie on the example of rolling profiles (rails type R65 and $R 24$ )

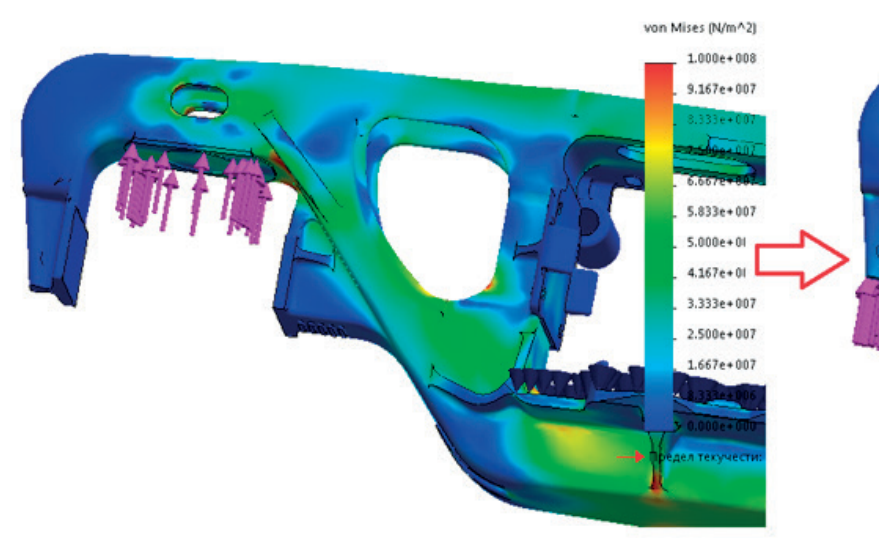

a)

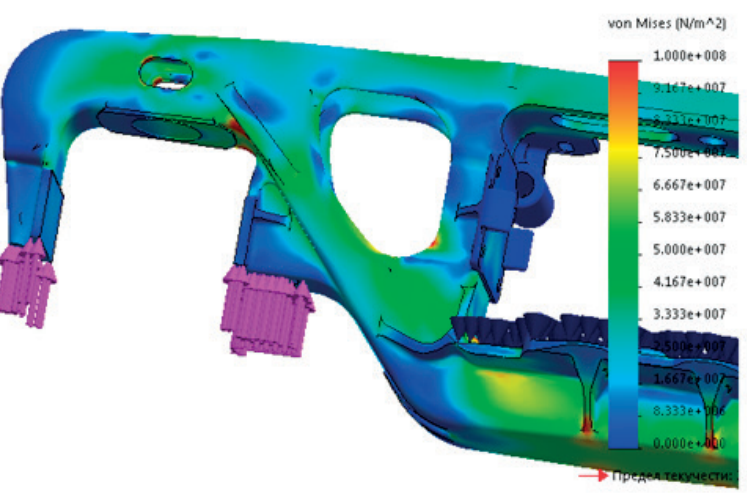

b)

Fig. 9 Diagrams of equivalent stresses for the existing (a) and prospective (b) schemes of vertical forces application 
As the first stage of the implementation of this direction, the authors have analyzed a number of existing profiles for the purpose of creating a rolling side frame of a three-piece bogie using standard rail profile R65 [18], rail profile R24 [19] and performed its strength calculations (Fig. 10). The results of comparing the mass and equivalent stresses of side frames made of these types of profiles are presented in Table 1. The transition from the cast to the rolling side frame contributes to a weight reduction of up to $30 \%$ while maintaining permissible stress levels.

\begin{tabular}{|c|c|c|c|c|c|}
\hline $\begin{array}{l}\text { Type of side } \\
\text { frame }\end{array}$ & $18-100$ & $18-9770$ & $\begin{array}{l}\text { With } \\
\text { rolling } \\
\text { R65 }\end{array}$ & $\begin{array}{l}\text { With } \\
\text { rolling R65 } \\
\text { and R24 }\end{array}$ & $\begin{array}{l}\text { With } \\
\text { rolling } \\
\text { R24 }\end{array}$ \\
\hline Masses, $\mathrm{kg}$ & $400-430$ & 450 & 420 & 324 & 308 \\
\hline $\begin{array}{l}\text { Maximum } \\
\text { stress levels } \\
\text { in horizontal } \\
\text { compression } \\
\text { member, } \\
\text { MPa }\end{array}$ & $70-80$ & $70-80$ & $65-75$ & $85-100$ & $100-120$ \\
\hline
\end{tabular}

\subsection{Using of elastic-damping multifunctional elements with modularity units}

The most promising approach to the creation of a freight car bogie from a number of technical solutions developed by the authors is the use of modular multifunctional load-bearing structural elements. As load-bearing modules, an equally stressed leaf spring is considered, which combines the functions of loadbearing and elastically dissipative elements. Conceptual designs of the three-piece bogie and Y-25 bogie, developed by the authors based on the principles of multifunctionality and modularity, are presented in Figs. 11 and 12 respectively.

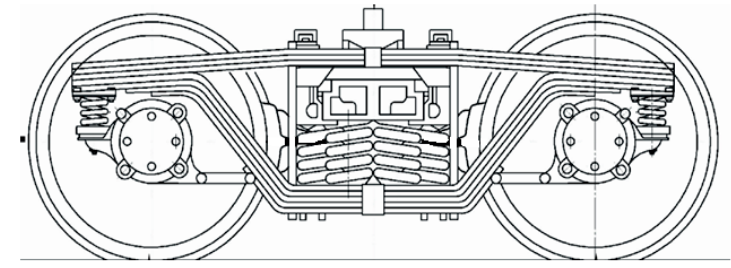

Fig. 11 Three-piece bogie with an elastic-dissipative frame concept

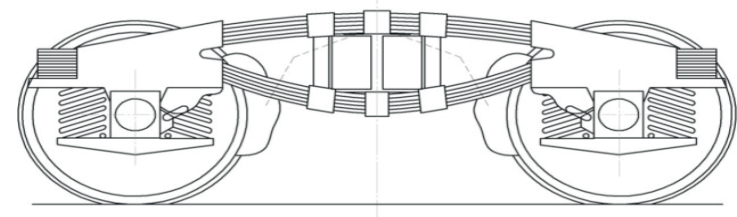

Fig. 12 Y-25 bogie with an elastic-dissipative frame concept Considering the international experience in the field of contact evaluation of wheel and rail stresses [20 - 21], bench and road tests of wheel-rail contact [22 - 24], dynamics modeling of a bogie [25 - 26], etc. [27], the object of further research is the simulation of the dynamics of cars with new types of bogies and their testing.

\section{Conclusions}

1. Analysis of the freight car bogies construction development for track gauge 1435 and $1520 \mathrm{~mm}$ indicates a significant lag in their technical characteristics over the needs of modern railway equipment. To achieve the priority tasks of transport formulated in the Shift 2 Rail work program, it is necessary to develop and implement breakthrough technical solutions.

2. The authors developed a technical solution for a three-piece bogie with pedestal jaw opening reinforcement by closing it with a pre-stressed element, which allows to reduce the level of maximum stresses in the most stressed zone R55 by 1.5-1.9 times, and also by creating on this basis a primary bogie suspension with a minimal change in the existing structure; this will reduce the resistance to movement by $11 \%$ and increase the maximum speed by $30 \%$.

3. The use of pre-stressed units in the bearing elements of the bogie makes it possible to reduce its weight and maximum operating stresses.

4. The concept of the original rolling bogie has been created on the example of a three-piece bogie and the strength calculations of the side frame and the bolster made of rolling profiles have been carried out. This allows reducing the mass to $30 \%$ while maintaining the permissible stress level, which indicates the prospect of the idea of finding the optimal rolling for the load-bearing elements of the bogie.

5. The most promising approach to the creation of a high-speed freight car bogie is the use of leaf springs as multifunctional bearing elements, which are close to an equally stressed state and provide both deflection and damping helping to minimize the mass of the bogie.

\section{Acknowledgements}

The research was conducted at the Department of Transport and Handling Machines of the Faculty of Mechanical Engineering of the University of Zilina within the frameworkof National Scholarship Programme of the Slovak Republic for the Support of Mobility of Students, PhD Students, University Teachers, Researchers and Artists and based on scientific research "Development of the scientific principles of diagnosis of mechanical transport systems on the basis of the analysis of dynamic oscillation processes of their elements", funded by the Ministry of Education and Science of Ukraine. 


\section{References}

[1] WHITE PAPER Roadmap to a Single European Transport Area - Towards a Competitive and Resource Efficient Transport System /* COM/2011/0144 final.

[2] Shift 2 Rail. Joint Undertaking. Multi-Annual. Action Plan. Brussels, November 2015, 818 p.

[3] JONSSON, P-A.: Dynamic Performance of Freight Wagons and their Influence on Cost for Track Deterioration. KTH Rail Vehicles, Teknikringen Royal Institute of Technology SE-100 44, Stockholm Sweden.

[4] IWNICKI, S. D. et al.: The 'SUSTRAIL' High Speed Freight Vehicle: Simulation of Novel Running Gear Design, in $23^{\text {rd }}$ Symposium on Dynamics of Vehicles on Roads and Tracks (IAVSD 2013) 2013, Qingdao.

[5] JONSSON, P.-A.: Dynamic Vehicle-Track Interaction of European Standard Freight Wagons with Link Suspension. Doctoral Thesis, Report TRITA AVE 2007:36, ISBN 978-91-7178-727-9, KTH Rail Vehicles, 2007.

[6] STICHEL, S, JONSSON, P.-A.: Is there a Future for Freight Wagon with Link Suspension? Proc. of the $9^{\text {th }}$ Intern. Heavy Haul Conference, IHHA'09, Shanghai, June 2009.

[7] GORBUNOV, N. I., MOKROUSOV, S. D., NOZHENKO, E. S., KRAVCHENKO, E. A., KARA, S. V.: The Question of the Truck Freight Cars (in Russian), Vestnik V. Dahl East : Ukrainian National University, No. 18 (207), 2013, 87-93.

[8] GORbUnOV, M. I., KARA, S. V., NOZHENKO, O. S., ANOFRIEV, A. D.: Perspective Directions of Increasing Strength Side Frames Freight Wagon Bogie (in Russian). Proc. of the State University of Economics and Technology of Transport, No. 26-27, 148-152.

[9] DOMIN, R. YU., GORBUNOV, M. I., KARA. S. V., DOMIN, YU. V., CHERNYAK, G. YU., NOZHENKO, O.S.: Patent for Utility Model No. 105480 (in Ukrainian), Method of Increasing Strength and Improving Dynamics of 3-Element Freight Bogie, k1. B61F 3/00, B61F 5/00, bul. No. 6, 2016.

[10] ORLOVA, A. M.: Hierarchical-iterative Method of Choosing Parameters of Power Characteristics and Constructive Solutions for Hanging Freight Wagon Carriages (in Russian), Transport of Ural, No. 2 (17), 2008, 35-42.

[11] DOMIN, R. YU., GORBUNOV, M. I., DOMIN, YU. V., NOZHENKO, O. S., CHERNYAK, G. YU., KARA, S. V., MOSTOVICH, A. V., KRAVCHENKO, K. O.: Patent for Utility, Model No. 104542 (in Ukrainian), Freight Car Bogie, k1. B61F 3/00, 10.02.2016, bul. No. 3, 2016.

[12] KOMAROVA, A. N.: The Impact on the Energy Efficiency Characteristics of Carts of Freight Cars (in Russian), PhD Thesis, SanktPetersburg, 2015, $88 \mathrm{p}$.

[13] ORLOVA A. M., RUDAKOVA E. A., TURUTIN I. V., SAIDOVA. A.: The Choice of the Design of the First Stage of Suspension of Three-Element Bogie of Innovative Freight Cars (in Russian), Izvestiya : Petersburg University of Communications, 2011, No. 3, 88-99.

[14] MAKHNENKO, O. V., SAPRYKINA, G. YU., MIRZOV, I. V., EMPTY, A. D.: Prospects for the Creation of Welded Structures of Load-Bearing Elements of a Freight Wagon Bogie (in Russian), Automatic Welding, No. 3 (730), 2014, 36-42.

[15] GORBUNOV, M. I., KARA, S. V., ANOFRIEV, A. D., MOKROUSOV, S. D., NAYSH, N. M., NOZHENKO, O. S., FOMIN, O. V.: Patent for Utility, Model No. 107125 (in Ukrainian), Bolster of Freight Car Bogie, kl. B61F 5/16, B61F 5/52, bul. No. 10/2016.

[16] GORBUNOV, M. I., KARA, S. V., ANOFRIEV, A. D., MOKROUSOV, S. D., NOZHENKO, O. S., FOMIN, O. V., KOVTANETS, M. V.: Patent for Utility, Model No. 107126 (in Ukrainian), Bogie Side Frame of a Freight Wagon, k1. B61F 5/52, B61F 5/30, bul. No. $10 / 2016$.

[17] DOMIN, R. YU., GORBUNOV, M. I., DOMIN, YU. V., NOZHENKO, O. S., CHERNYAK, G. YU., KARA, S. V., MOSTOVICH, A. V., KRAVCHENKO, K. O.: Patent for Utility, Model No. 104539, Bogie Side Frame of a Freight Wagon (in Ukrainian), k1. B61F 5/52, B61F 5/30, bul. No. 13/2016.

[18] GOST R 51685-2000. Railway Rail. General Specifications (in Russian).

[19] GOST 6368-82. Railway Rail for Narrow Track Gauge of the Types R8, R11, R18 i R24. Design and dimensions.

[20] LACK, T., GERLICI, J.: Wheel/Rail Tangential Contact Stress Evaluation by Means of the Modified Strip Method. Communications - Scientific Letters of the University of Zilina, vol. 16, No. 3A, 2014, 33-39. ISSN 1335-4205.

[21] LACK, T., GERLICI, J.: Wheel/Rail Contact Stress Evaluation by Means of the Modified Strip Method. Communications Scientific Letters of the University of Zilina, University of Zilina, vol. 15, No. 3, 2013, 126-132. ISSN 1335-4205.

[22] GERLICI, J., GORBUNOV, M., KRAVCHENKO, K., KOSTYUKEVICH, A., NOZHENKO, O., LACK, T.: Experimental Rigs for Wheel/Rail Contact Research, J. Manufacturing Technology, vol. 16, No. 5, 2016, 909-916. ISSN: 1215-2489.

[23] SPIRYAGIN, M., YOO, H. H., LEE, K. S., SPIRYAGIN, V., GORBUNOV, M.: Investigation of Influence of Constraints with Radius Links on Locomotive Axle Load Distribution and Wheelset Steering Ability, J. of Mechanical Science and Technology, 27 (7), 2013, 1903-1913. 
[24] KOSTYUKEVICH, A., GORBUnOV, N., NOZHENKO, V., KOVTANETS, M. TSYGANOVSKIY, I.: Friction Interaction Management in Two-Point "Wheel-Rail” Tribocontact. Transport Problems: an Intern. Scientific J., vol. 7, No. 3, 2012, p. 53.

[25] MYAMLIN, S. V., LINGAITIS, L. P., DAILYDKA, S., VAICIUNAS, G. M., BOGDEVICXIUS, M., BUREIKA, G.: Determination of the Dynamic Characteristics of Freight Wagons with Various Bogie. Transport, vol. 30 (1), 2015, 88-92.

[26] BUbnOV, V. M., MYAMLIN, S. V., MANKEVYCH, N. B.: Dynamic Performance of Freight Cars on Bogies Model 18-1711. Nauka ta progres transportu, No. 4 (46), 2013, 118-126.

[27] MOGILA, V., VASYLIEV, I., NOZHENKO, E.: The Use of Biofuel on the Railway Transport, Transport Problems, vol. 7, No. 1, 2012,21-26. 